\title{
A APREENSÃO DO ACONTECIMENTO NAS CAPAS DE NEWSMAGAZINES ${ }^{1}$
}

THE COMPREHENSION OF THE EVENT IN NEWSMAGAZINES COVERS

\section{LA COMPRENSIÓN DEL ACONTECIMIENTO EN LAS PORTADAS DE REVISTA}

\author{
Paulo Bernardo Ferreira Vaz \\ Professor do Programa de Pós-Graduação em Comunicação Social da UFMG \\ paulobvaz@gmail.com \\ Vanessa Costa Trindade \\ Mestranda do Programa de Pós-Graduação em Comunicação Social da UFMG \\ vancotrin@gmail.com
}

\section{Resumo}

A cada semana, Veja, IstoÉ, Carta Capital e Época dispõem elementos verbais e visuais em suas capas, a partir dos quais os leitores - habituais e inabituais - vão poder construir sentidos para os temas colocados em revista. Em uma tentativa de apontar caminhos para compreender como se dá essa construção, a proposta deste trabalho é pensar as capas de newsmagazines, ilustrações inclusive, como um texto e pensar no texto como uma forma de apreensão do acontecimento. Dentre os temas destacados nas capas das quatro revistas, recortamos um acontecimento específico - o das eleições presidenciais brasileiras de 2010 - dada a importância fundamental dos acontecimentos para a mídia em geral, e para as newsmagazines, em especial.

Palavras-chave: Capas de newsmagazines. Texto. Acontecimento.

\begin{abstract}
Each week, Veja, IstoÉ, Carta Capital and Época have verbal and visual elements on the first page, from which readers - usual and unusual - will be able to construct meaning for the themes printed in these four newsmagazines. In an attempt to point out ways to understand how is this construction, the purpose of this paper is to think the covers of newsmagazines, including illustrations, such as a text and think about the text as a way of apprehending the event. Among the topics highlighted on the cover of these magazines, we chose a specific event - the Brazilian presidential elections of 2010 - given the fundamental importance of events for the media in general and for newsmagazines in particular.
\end{abstract}

Keywords: Newsmagazines cover. Text. Event.

Esta obra está licenciada sob uma Licença Creative Commons

\footnotetext{
${ }^{1}$ Trabalho apresentado no GP Produção Editorial, XI Encontro dos Grupos de Pesquisas em Comunicação, evento componente do XXXIV Congresso Brasileiro de Ciências da Comunicação (Setembro de 2011).
} 


\section{Resumen}

Todas las semanas, Veja, IstoÉ, Carta Capital y Época disponen elementos verbales y visuales en sus portadas, a partir de las cuales los lectores - comunes e inusuales - pueden construir el significado de los temas puestos en revista. En un intento por destacar maneras de entender cómo es esta construcción, el objetivo de este trabajo es pensar en las portadas de las revistas de noticias, incluyendo las ilustraciones, como un texto y pensar en el texto como una manera de aprehender el acontecimiento. Entre los temas destacados en la portada de cuatro revistas, elegimos un evento específico - las elecciones presidenciales brasileñas de 2010 dada la importancia fundamental de los acontecimientos para los medios de comunicación en general y para las revistas de noticias en particular.

Palabras clave: Portadas de revista. Texto. Acontecimiento.

\section{INTRODUÇÃO}

Semanalmente as newsmagazines brasileiras - Veja, IstoÉ, Carta Capital e Época fazem circular juntas 1.864.906 exemplares ${ }^{2}$. Entretanto, este número de exemplares atinge ainda mais receptores, pois a revista circula por uma quantidade bem maior de pessoas que cercam os compradores habituais e assinantes: aqueles que vez ou outra as tomam de empréstimo ou lançam miradas pelas capas e folheiam as revistas nas bancas da cidade. Newsmagazines têm a capa como vitrine. Por isso, ela é organizada com ilustrações, manchetes e chamadas para dizer dos temas estampados nas capas, entre os quais acontecimentos, da forma mais atraente possível. Cabe às capas o primeiro contato com o leitor. É delas a função de convencê-lo a levar a revista para casa. Por isso, deve ser o "resumo irresistível de cada edição" (SCALZO, 2008, p.62).

Imaginemos, então, uma pessoa que tome contato com os acontecimentos destacados pelas newsmagazines apenas por essas visadas das capas. Como tal leitor pode atribuir sentidos ao que ocorre no mundo a partir das capas dessas várias publicações hebdomadárias vistas tanto individualmente como em um conjunto das várias edições semanais? Numa tentativa de refletir sobre essa questão, propomos pensar a capa das revistas semanais de informação como texto e o texto como forma de apreensão do acontecimento ali estampado.

As eleições presidenciais compuseram um dos acontecimentos mais relevantes para a sociedade brasileira no segundo semestre de 2010, temática estampada em capas sucessivas.

\footnotetext{
${ }^{2}$ Dados do Instituto Verificador de Circulação (IVC), referentes à circulação média entre janeiro a junho de 2010. Os dados por revista são: Veja - 1.083.742 exemplares; IstoÉ - 341.929 exemplares; Carta Capital 30.207 exemplares; Época - 409.028 exemplares. Informações disponíveis no site da Associação Nacional dos Editores de Revista (ANER): http://www.aner.org.br/Conteudo/1/artigo42424-1.asp. Acesso em 13/11/2010.
} 
No dia 3 de outubro ocorreu o primeiro turno das eleições, disputado por nove candidatos ${ }^{3}$. Os dois mais bem votados, Dilma (PT) e Serra (PSDB), foram para a disputa em segundo turno, ocorrido no dia 31 de outubro, quando a candidata petista ganhou com 56,05\% dos votos. Entre um e outro turno recortamos um total de 20 edições de Veja, IstoÉ, Carta Capital e Época, sendo que 18 delas tiveram as eleições como principal assunto de capa. Na semana posterior ao segundo turno, as quatro newsmagazines lançaram edições "extras" e "especiais" sobre a vitória de Dilma Rousseff. Obtivemos, assim, um recorte privilegiado para encetar o nosso estudo.

\section{DE UMA ÚNICA... A UM CONJUNTO DE CAPAS}

As capas das newsmagazines tanto operam na seleção de acontecimentos diários, que alimentam as páginas dos informativos e o cotidiano dos sujeitos, quanto são afetadas por grandes acontecimentos que irrompem o cotidiano. Vaz e França (2009), ao analisar os acontecimentos nas capas da revista Veja, fazem uma distinção entre aqueles que seriam os acontecimentos legítimos, esses grandes acontecimentos que afetam a mídia, e aqueles que seriam os acontecimentos legitimados, os acontecimentos cotidianos, selecionados por ela para serem ofertados ao público.

Quéré (2005), no texto "Entre facto e sentido: a dualidade do acontecimento", falando do acontecimento legítimo, constrói sua argumentação a partir de uma crítica à recorrência nas ciências sociais de compreender o acontecimento sob o modo da causalidade, como se ele fosse a consequência, o resultado, o fim de um processo. Em oposição a esse modo, propõe levar em conta a dimensão hermenêutica do acontecimento, preocupando-se com valores e significações que lhe são atribuídos pelos sujeitos. Segundo esse autor, o acontecimento precisa acontecer a alguém (indivíduo ou coletividade) para "se tornar". É necessário que um sujeito o integre num sistema de pensamento para que ele adquira significação. Enquanto fenômeno hermenêutico, o acontecimento é compreendido através de suas causas, porém, também faz compreender, revela. Seria o fim e o início.

Ainda de acordo com Quéré (2005), a ocorrência de um acontecimento tanto pode produzir uma descontinuidade, perceptível em meio à continuidade, quanto pode ser esperada, desde que faça emergir algo novo. Quando um acontecimento se produz, continua o autor, o

\footnotetext{
${ }^{3}$ Os principais candidatos foram Dilma Rousseff (Partido dos Trabalhadores - PT), José Serra (Partido da Social Democracia Brasileira - PSDB), Marina Silva (Partido Verde - PV) e Plínio de Arruda Sampaio (Partido Socialismo e Liberdade - PSOL). Os outros cinco candidatos não alcançaram $1 \%$ das intenções de voto.
} 
mundo não é mais o mesmo. "Por isso, fazemos tudo quanto está ao nosso alcance para reduzir as descontinuidades e para socializar as surpresas provocadas pelos acontecimentos" (Quéré, 2005, p.04). Tanto ligamos o acontecimento a um passado de que ele é ponto de chegada quanto o incluímos em um contexto no qual ele se integra de forma coerente e aparece como algo previsível - sendo que esse passado e esse contexto não preexistiam ao próprio acontecimento.

Da tentativa de se compreender o que está acontecendo forma-se uma intriga, um enredo. Não se trata, para Vaz e França, apenas de uma história em torno do tema, mas da instauração de um campo problemático, que envolve os conflitos, tensões e contradições ligados ao acontecimento. Este, entretanto, também tem poder de esclarecimento, sendo o pivô de inquéritos que buscam por soluções.

Esses acontecimentos que têm poder de quebra do cotidiano, que rompem expectativas, obrigariam sua reverberação pela mídia. Todavia, lembram Vaz e França, a mídia não se alimenta somente desse acontecimento legítimo, que se dá de tempos em tempos. Ela legitima outros acontecimentos que não têm poder de reverberação própria.

De acordo com Charaudeau (2006), o acontecimento é selecionado para virar informação em função de três potenciais: 1) atualidade, segundo a distância entre o momento de aparição do acontecimento e o da informação; 2) sociabilidade, conforme a aptidão em representar o que acontece num mundo em que o que está organizado coletivamente não deve ser estranho aos indivíduos; 3) imprevisibilidade, que diz respeito à capacidade de perturbar a tranquilidade dos sistemas de expectativas do sujeito que se informa.

No momento em que os acontecimentos se dão, não existe nada para ser visto (MOUILLAUD, 2002, p.49), eles não são inteligíveis (CHARAUDEAU, 2006, p.95). “O acontecimento", diz Charaudeau (2006, p.99), "nasce, vive e morre numa dialética permanente da ordem e da desordem, dialética que pode estar na natureza, mas cuja percepção e significância dependem de um sujeito que interpreta o mundo".

Para Mouillaud, os meios de comunicação encontram-se no fim de uma cadeia de transformações do acontecimento que traz um real já domesticado. E os sentidos que levam aos leitores são remanejados por estes a partir de seu próprio campo mental antes de serem recolocados em circulação no ambiente cultural. Ainda de acordo com ele, os acontecimentos são duplamente fragmentados. Na origem, são extraídos de uma experiência que permanece fora do texto, na chegada, aparecem entre outras informações. A experiência não é reprodutível, está ligada a um espaço e a um momento no tempo, já o acontecimento, 
veiculado pela informação, é móvel, é um fragmento de uma totalidade que não pode ser compreendida por si só. Para explicar essa relação, o autor toma emprestado à fotografia e ao cinema o conceito de enquadramento.

\begin{abstract}
Aparentemente, a moldura é posterior ao quadro, mas o quadro procede de um enquadramento implícito que o precedeu. A moldura opera ao mesmo tempo um corte e uma focalização: um corte porque separa um campo e aquilo que o envolve; uma focalização porque, interditando a hemorragia do sentido para além da moldura, intensifica as relações entre os objetos e os indivíduos que estão compreendidos dentro do campo e os reverbera para um centro. [...] A moldura, isolando um fragmento da experiência, separa-o de seu contexto e permite sua conservação e seu transporte (MOUILLAUD, 2002, p.61).
\end{abstract}

Conforme Vaz e França, diferentemente do que ocorre com os acontecimentos legítimos, é a estratégia de exposição de cada veículo que vai determinar a existência e importância dos acontecimentos legitimados. Enquanto os grandes acontecimentos têm o poder de afetar a mídia e não necessitam dos veículos para serem legitimados, os acontecimentos cotidianos precisam ser selecionados para ganharem visibilidade. Todavia, é no tratamento que dá aos acontecimentos legítimos que o jornalismo constrói sua forma para dar conta de legitimar outros acontecimentos. A distinção entre um tipo e outro de acontecimento não pretende colocá-los em pólos opostos. Seus limites são tênues e, muitas vezes, pode haver uma hibridização no momento de publicização. Vaz e França propõem pensar em acontecimentos legítimos e legitimados como faces dos meios de comunicação na produção de sentido e afetação da vida dos sujeitos.

As revistas semanais de informação existem nesse lugar de organização, hierarquização e socialização dos acontecimentos. Elas estão entre os vários materiais simbólicos mobilizados pelos sujeitos para atribuir significados ao que acontece. E isso é feito de um modo específico, elas têm uma forma característica de configurar os acontecimentos que as distingue de outros meios de comunicação. Para considerar suas peculiaridades, as tomamos como dispositivos que articulam:

1) uma forma específica de manifestação material dos discursos, de formatação de textos; 2) um processo de produção de significação, de estruturação de sentidos; 3) uma maneira de modelar e ordenar os processos de interação; e 4) um procedimento de transmissão e difusão de materiais significantes (ANTUNES; VAZ, 2006, p.47). 
Essa noção de dispositivo é uma tentativa de ultrapassar a ideia de suporte técnico para pensar o acontecimento em tais revistas, mais especificamente em suas capas. Cardoso (2007) toma a própria capa da newsmagazine como dispositivo de comunicação. Para isso, parte do desenvolvimento do conceito por Deleuze, que associa dispositivo à meada, a um conjunto multilinear, formado por linhas de natureza diferente; e por Foucault, que o associa a uma rede que pode ser estabelecida entre os elementos. O dispositivo seria uma figura intermediária entre uma abordagem totalizante que coloca em evidência a ideia de uma estrutura homogênea e outra, rizomática, que evidencia uma fluência generalizada, conjuntos complexos abertos (CARDOSO, 2007, p.590). Para a autora, a capa pode ser vista como essa figura intermediária, pois faz parte da publicação e, ao mesmo tempo, se demarca dela, vale por si só. Uma reunião de capas, continua Cardoso, pode ser vista tanto como algo que segue uma estratégia específica de organização, que permite lê-las de forma homogênea, quanto como um conjunto complexo.

Ainda de acordo com Cardoso, ao dispositivo "subsiste a intenção de articular os meios em função de um fim" (CARDOSO, 2007, p.591). E também essa característica se aplica à capa de revista, que, para a autora, tem como fim a sedução. Assim, a capa de cada newsmagazine atua na construção dos acontecimentos autonomamente - escolhendo manchete, ilustração e chamada para dizer do que ocorre - e em conjunto com outras dispostas nas bancas e na memória de seus espectadores. Nos dois casos, as possibilidades de atribuição de significados são amplas e diversificadas.

A partir da cobertura realizada pelas revistas semanais de informação brasileiras do acidente com o airbus A-320 da TAM - ocorrido no aeroporto de Congonhas, São Paulo, em julho de 2007 -, Vaz (2009) propõe olhar para as capas dessas publicações como interfaces discursivas apropriadas tanto por aquele leitor habitual quanto por pessoas que transitam nas bancas de revistas em que são expostas para venda.

O flagrante da exposição das capas em bancas permite a recomposição de conversações, diálogos e até monólogos propostos pelos veículos, empreendidos e apreendidos pelos leitores que se apropriam de sentidos naquele importante espaço da mídia impressa (VAZ, 2009, p.1).

Segundo o autor, a simples disposição das revistas nas bancas, que é realizada aleatoriamente pelo jornaleiro, pode proporcionar diversas leituras do acontecimento narrado. As quatro capas publicadas na semana seguinte ao acidente aéreo permitem, por exemplo, 24 modos de ordenar a exposição, 24 possibilidades de apreciação. 
Para desenvolver seu pensamento, Vaz se apropria do princípio do ideograma que Eisenstein destaca em composições no cinema e em outras artes e o aplica nas capas das newsmagazines. Esse princípio, de forma bastante simplificada, diz que a combinação de dois hieróglifos não deve ser considerada como sua soma, mas como correspondente a um conceito. Desse modo, o ideograma, formado por hieróglifos, seria um conceito. A aplicação desse princípio de composição ideográfica na disposição das capas de revistas permite vê-las como uma forma de "escrita figural".

Ao observar as capas das quatro revistas, quatro objetos, falamos de visualidades que correspondem a quatro hieróglifos que justapostos, propiciam a leitura figural de um conceito só formado na mente do espectador, através da combinação encontrada na banca. Até transeuntes analfabetos podem ler essa escrita figural (VAZ, 2009, p.4).

Com a mudança da disposição das capas nas bancas, muda o conceito proposto. Além disso, o leitor pode associar não apenas as capas de uma mesma semana entre si, mas também capas de semanas diferentes. As opções são múltiplas.

Ideia semelhante é trabalhada no Animalário do Professor Revillod, de Miguel Murugarren e Javier Sáez Castán, publicado em português pela editora Orfeu Negro em $2009^{4}$. Trata-se de um pequeno almanaque que compila dezesseis ilustrações de animais com seus respectivos nomes ao pé dos desenhos. O desenho de cada animal é dividido em três partes móveis, organizados de modo a se obter 4096 combinações entre elas. Resultam, portanto, 4096 desenhos de animais não encontráveis na natureza, posto que se trata de uma (re)criação do leitor ao proceder a (re)composição das 48 peças (16 x 3). O nome do animal, por sua vez, é também dividido em sílabas, permitindo que no movimento das páginas possam se formar 4096 nomes de cada animal (re)criado com a manipulação pelo leitor. Completando o Animalário, acha-se um pequeno texto no verso do desenho/nome. Também dividido em três partes, este texto traz uma curta definição de cada um dos 16 animais mostrados. A cada mudança na combinação das partes do Animalário (desenho e nome do animal, à frente) muda a definição do animal formado, no verso, com seus respectivos 4096 textos explicativos.

Por exemplo, a mistura da cabeça de um TI-GRE, com o dorso de um ELE-FAN-TE e o rabo de um TA-TU, forma um exótico "TI-FAN-TU" que ganha o texto complementar: "animal feroz de porte majestoso da região do Orinoco" (FIG. 1).

\footnotetext{
${ }^{4}$ A edição original, Animalario del Profesor Revillod, é do ano de 2003.
} 


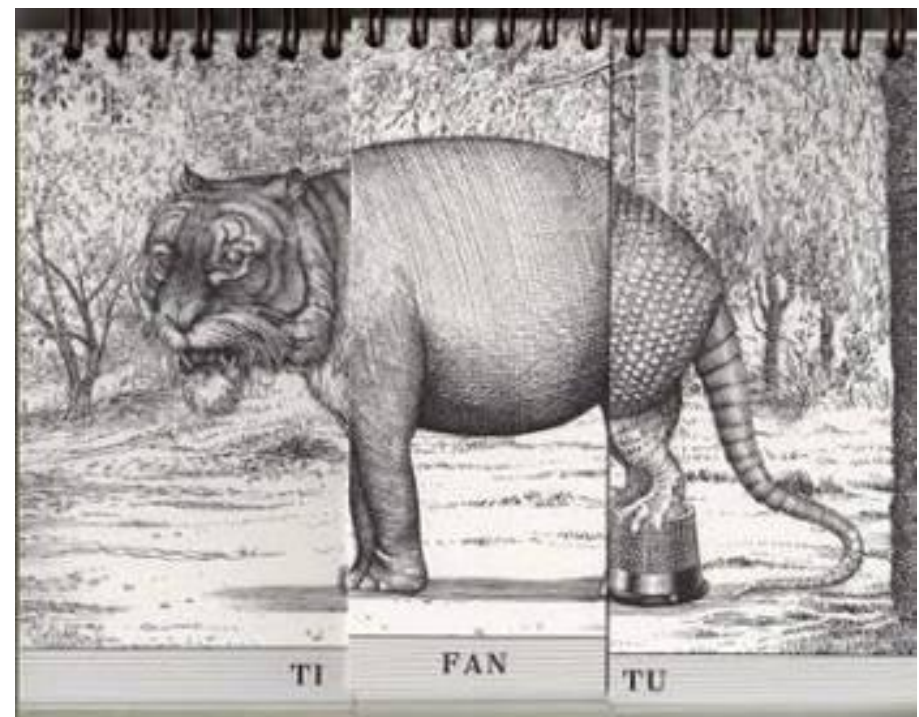

A ideia desenvolvida por Vaz em seu artigo sobre capas de revistas e a proposta lúdica do Animalário do Professor Revillod propõem um olhar tanto para cada capa individualmente quanto para a disposição das mesmas nas bancas e também nas mentes dos leitores. Individualmente, cada uma das revistas vai selecionar ilustração, manchete, chamadas, enfim, vários elementos para dizer, logo na capa, do principal acontecimento que se propõe a tratar. Cada capa, reunindo todos esses elementos, é um conceito, diz do acontecimento escolhido para ocupar aquele lugar de modo inédito. Em conjunto, possibilitarão um leque ainda mais amplo de leituras e atribuição de significados. Mas como apreender esse acontecimento que pode ter tantos sentidos? Propomos pensar na noção de texto como um caminho possível.

\section{A CAPA COMO TEXTO E O TEXTO COMO FORMA DE APREENSÃO DO ACONTECIMENTO}

Embora seja muito comum a associação do termo "texto" ao que é verbal, a noção com a qual trabalhamos envolve também os aspectos visuais. Kress, Leite-Garcia e van Leeuwen propõem (2000) uma semiótica discursiva, ou semiótica social, para pensar os textos segundo a lógica da multimodalidade - observando, em conjunto, esses aspectos verbais e visuais. A página seria, para eles, uma unidade de compreensão.

Se os textos são sempre multimodais, então a questão das fronteiras de um texto se converte em um problema central. Em qualquer página, é bastante 
problemático ler somente a significação transmitida de modo linguístico ${ }^{5}$ (KRESS, LEITE-GARCIA, VAN LEEUWEN, 2000, p.390). [tradução nossa]

A ideia de ir além da linguística para analisar os textos se justificaria pelo fato de mesmo o escrito ter um registro visual. A letra, por exemplo, é um desenho, por isso é tão importante olhar para outros elementos para além dos verbais. Contudo, não se trata de abandonar a linguística, até porque sua exatidão metodológica é de grande relevância, mas de complementá-la com abordagens de outras áreas, como o cinema.

Embora a página seja apontada como uma unidade de significação, esses autores veem o texto como um lugar vivo, que gera novas produções textuais. O texto é, por isso, ao mesmo tempo fechado e aberto. É importante salientar, ainda, que a noção de texto com a qual trabalhamos percebe o texto para além de sua materialidade empírica. Ele resulta de uma interpretação, envolve outros textos. Além disso, como o texto faz parte de uma história e de uma cultura, sua dimensão ideológica é um pressuposto. Tanto os produtores como os leitores têm poder em relação com o texto.

Escrever é produzir um novo signo exteriormente - um texto - com os recursos disponíveis para o escritor, ler é produzir um novo signo "interiormente" com os recursos disponíveis para o leitor, dos quais o texto que se lê é o elemento central ${ }^{6}$ (KRESS, LEITE-GARCIA, VAN LEEUWEN, 2000, p.390). [tradução nossa]

Abril (2007) compartilha de uma noção de texto bastante próxima desta. Para ele, o texto é dinâmico, se constitui o tempo todo. Além disso, está ligado a uma rede textual. Sendo assim, os destinatários jamais recebem mensagens particulares, mas conjuntos textuais, avalanches de texto que chegam incessantemente. E é na leitura que se produz uma outra significação para o texto. De acordo com esse autor, é de particular importância desmentir que a interpretação esteja ligada à decodificação de mensagens. Ele entende que as atividades de emissão e recepção são interdependentes, ambas se condicionando.

O sujeito que produz um texto normalmente antecipa estrategicamente a interpretação-resposta de seu destinatário; ao interpretá-lo, este propõe certas

\footnotetext{
${ }^{5}$ Do original: "Si los textos son siempre multimodales, entonces la cuestión de las fronteras de un texto se convierte en un problema central. En cualquier página, resulta en alto grado problemático leer solamente la significación transmitida de modo linguístico."

${ }^{6}$ Do original: "Escribir es producir un nuevo signo exteriormente - un texto - con los recursos disponibles para el escritor; leer es producir un nuevo signo "interiormente" con los recursos disponibles para el lector, de los cuales el texto que se lee es el elemento central."
} 
hipóteses sobre os propósitos do sujeito produtor, sobre a forma textual e o contexto, etc. ${ }^{7}$ (ABRIL, 2007, p.24). [tradução nossa]

Os agentes sociais da comunicação não são simplesmente codificadores e decodificadores, mas sujeitos dotados de competência comunicativa, dessa capacidade de produzir e interpretar expressões linguísticas de forma contextualizada.

O sentido, diz Abril, é fluido. Mesmo que alguns discursos pareçam fechar suas possibilidades de leitura, os textos funcionam como um sistema complexo de significação. A partir de suas denotações é possível fazer conotações infinitamente.

Flusser (2010), partindo da etimologia da palavra, caracteriza texto como tecido. “Textos são, contudo, tecidos inacabados: são feitos de linhas (da 'corrente') e não são unidos, como tecidos acabados, por fios (a 'trama') verticais" (FLUSSER, 2010, p.51). O acabamento do texto ficaria a cargo da recepção. Ele estaria sempre em processo, sempre a ser completado pelo leitor para ganhar significados. "O texto tem, pois, tantos significados quanto o número de leitores" (FLUSSER, 2010, p.51).

Desse modo, desde o princípio, o texto pressupõe um leitor e pressupõe também outros textos. No primeiro caso, o outro é um pressuposto desde a escrita. Quem escreve um texto pensa em para quem está escrevendo. No segundo, "é comum a todos os textos serem braços estendidos que procuram com ou sem esperança ser abraçados por outros" (Flusser, 2010, p.54). Durante a leitura vão entrar em jogo todos os outros textos com os quais cada leitor já teve contato e também todos os textos aos quais o texto lido faz referências.

Compartilhando da noção trabalhada por esses autores, tomamos a capa da newsmagazine como um texto. A princípio, a seleção do acontecimento e dos elementos gráficos para contá-lo nas capas pressupõe um leitor. Também de antemão, a capa faz referência a outros textos. Cada leitor, por sua vez, vai atribuir significados às capas a partir das capas organizadas ao bel-prazer dos jornaleiros e de outros textos com que teve contato anteriormente. Observar a capa como um texto, todavia, não implica em pensá-la apenas em sua concretude material. Ela é eleita como uma unidade de significação para pensar o acontecimento, mas não se encerra nela mesma, não diz da totalidade. Ela se encaixa a outros textos e requer uma interpretação para significar.

\footnotetext{
${ }^{7}$ Do original: "El sujeto que produce un texto normalmente há de anticipar estratégicamente la interpretación-respuesta de su destinatário; al interpretarlo, éste propone ciertas hipótesis sobre los propósitos del sujeto productor, sobre la forma textual y el contexto, etc."
} 


\section{O CONJUNTO, SINCRÔNICO E DIACRÔNICO}

É nesse sentido que apostamos na noção de texto aqui trabalhada como forma de apreender o acontecimento nas capas das newsmagazines, buscando compreender a natureza do acontecimento nesses dispositivos. Tentamos entender como o texto verbal é combinado ao imagético nas capas de tais veículos para (re)configurar o acontecimento e que dinâmica é estabelecida pelas combinações entre as diferentes capas para construir o acontecimento nas mentes dos leitores. Tomamos a cobertura das eleições presidenciais brasileiras de 2010, realizada por Veja, IstoÉ, Carta Capital e Época, para observar como o acontecimento que pode ser indiciário disso.

Selecionamos as capas das 20 edições dessas quatro newsmagazines brasileiras publicadas desde a semana posterior ao primeiro turno das eleições 2010 - que ocorreu em 03 de outubro -, até as quatro capas da semana posterior ao segundo turno - ocorrido no dia 31 do mesmo mês. No recorte estão incluídas as "edições extras" publicadas por Veja, IstoÉ e Época sobre a candidata eleita. Carta Capital publicou sua "edição especial" na semana seguinte à eleição, onde estampou na capa foto de Dilma Rousseff sob a manchete "Mulher e Presidente", dedicando, além da capa, 15, do total de 76 páginas, à cobertura do acontecimento "vitória na eleição". O período recortado nos forneceu 24 capas.

Neste artigo limitamo-nos a realizar uma análise dessas capas em seu conjunto, em um movimento que contempla dois eixos: sincrônico e diacrônico (FIG. 2). O sincrônico (seta lilás), horizontal, decorre da mirada das capas das quatro revistas editadas numa mesma semana, dispostas de diferentes modos nas bancas; o diacrônico (seta azul), que tanto pode ser vertical quanto diagonal, é constituído pela mirada das capas veiculadas em semanas distintas, pensando nas possibilidades de associação entre uma capa e outra nas mentes dos leitores dentro de um período superior a sete dias. 
Figura 2 - Eixos de análise sincrônico e diacrônico

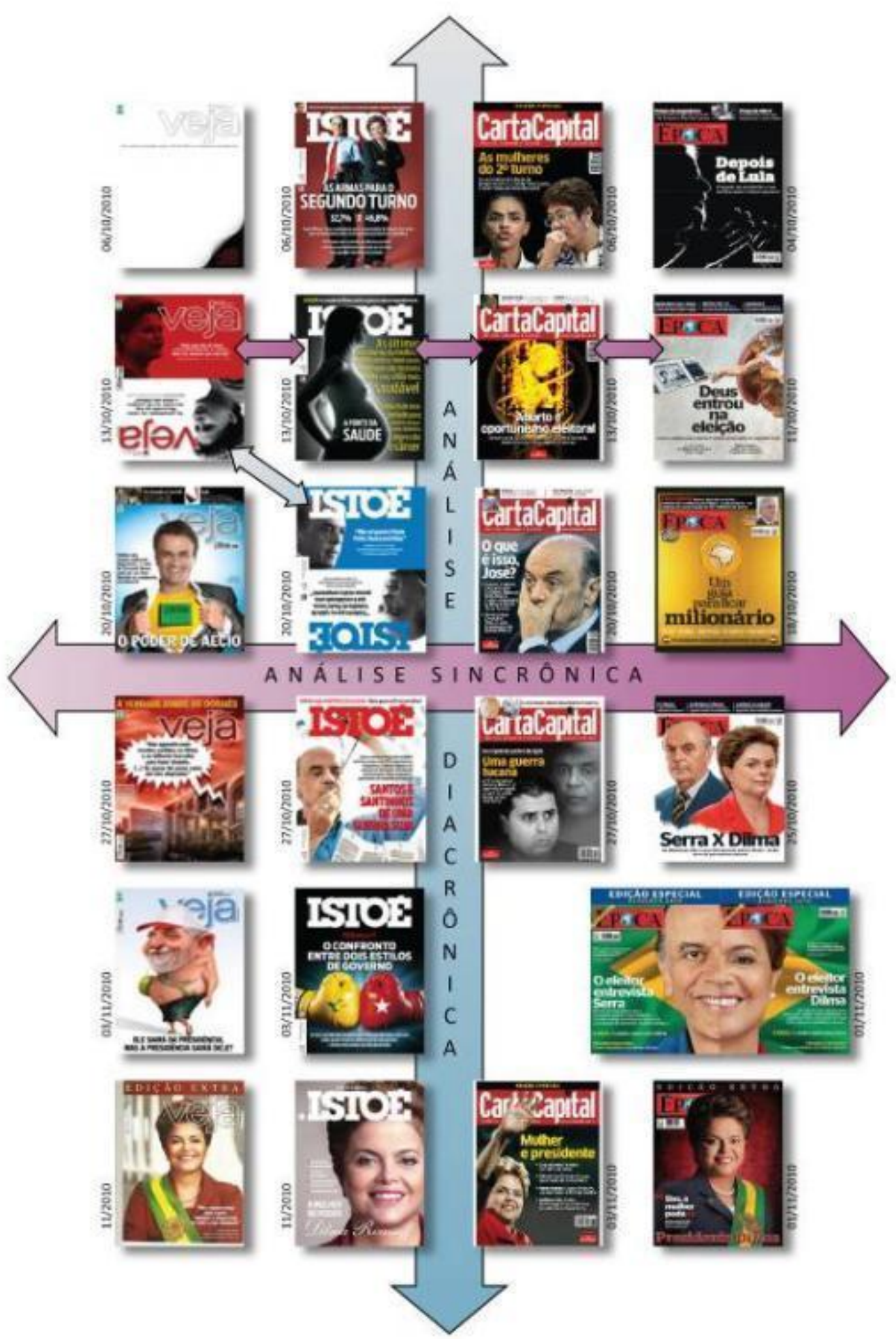


Destacamos a relação entre as newsmagazines publicadas na segunda semana após o primeiro turno. Num momento em que boatos sobre o posicionamento de Dilma com relação ao aborto vieram à tona e controvérsias sobre aborto e religião tomaram conta da disputa presidencial, Veja, Carta Capital e Época estamparam o assunto em suas capas. IstoÉ optou por falar de gravidez, mantendo-se associada ao assunto ${ }^{8}$.

Sincronicamente, tomando ilustração principal e manchete de capa, podemos ler:

a) Veja reproduz o layout de uma carta de baralho. A fotografia do rosto de Dilma, em meio-perfil, em preto, com um fundo em vermelho vivo que lembra sangue, mas que também faz referência à cor do PT, é acompanhada da fala, como um balão de HQ: "Acho que tem de haver a descriminalização do aborto. Acho um absurdo que não haja" / Dilma Rousseff, em 4 de outubro de 2007; e, de cabeça para baixo, aparece a mesma foto, em preto sobre fundo branco, com a seguinte fala:"Eu pessoalmente, sou contra. Não acredito que haja uma mulher que não considere o aborto uma violência" / Dilma Rousseff, em 29 de setembro de 2010; de cabeça para baixo apenas o logotipo de Veja aparece em vermelho-sangue;

b) IstoÉ estampa, em preto e branco, a foto de uma mulher grávida nua, de perfil, irradiando luz com a manchete "A fonte da saúde" sobre sua barriga;

c) Carta Capital opta pela ilustração de um feto iluminado sobre um fundo negro, rodeado por fitas de DNA, acima da manchete "Aborto e oportunismo eleitoral";

d) Época entra com a manchete "Deus entrou na eleição" sobre uma montagem feita a partir da obra A criação de Adão, de Michelangelo, onde o dedo de Deus - ao invés de tocar em Adão - aponta para a tecla "confirma" de uma urna eletrônica que mostra Dilma e Serra, trazendo o teto da Capela Sistina para o cenário político brasileiro.

Uma mudança nesta ordem permite, por exemplo, esta nova leitura:

a) IstoÉ mostra uma mulher grávida nua, que irradia luz e sobre sua barriga lê-se: “ $A$ fonte da saúde";

b) Veja traz a carta-de-baralho-Dilma, em vermelho e preto, fala, respectivamente de cabeça para cima e de cabeça para baixo: "Acho que tem de haver a descriminalização do aborto. Acho um absurdo que não haja” / Dilma Rousseff, em 4 de outubro de 2007 e "Eu pessoalmente, sou contra. Não acredito que haja uma mulher que não considere o aborto uma violência" / Dilma Rousseff, em 29 de setembro de 2010;

\footnotetext{
${ }^{8}$ Além disso, a revista traz a seguinte chamada no topo da capa: "ELEIÇÃO A cruzada de Dilma contra a guerra suja no segundo turno". Uma referência às opiniões atribuídas à candidata do PT com relação à descriminalização aborto, usadas contra ela de modo descontextualizada.
} 
c) Época diz que "Deus entrou na eleição" sobre uma imagem-ícone da Capela Sistina e de uma urna eletrônica que mostra Dilma e Serra;

d) Carta Capital dá em manchete "Aborto e oportunismo eleitoral" sobre a ilustração de um feto iluminado sobre um fundo negro, rodeado por fitas de DNA.

As séries acima apresentadas são apenas duas entre muitas outras possibilidades de combinação dessas capas que permitem variados modos de construção e apreensão dos acontecimentos estampados nas newsmagazines nesta semana. É possível lembrar-se da ilustração de uma, da manchete de outra, das chamadas de uma terceira revista.

Conforme se pode observar na FIG. 2, damos destaque, ainda, à relação diacrônica entre a capa de Veja do dia 13/10/2010 e a capa de IstoÉ da semana seguinte, datada 20/10/2010. Ambas se apropriam do layout de uma carta de baralho, algo de reconhecimento mundial, muito atraente para que o leitor entre na proposta lúdica das duas revistas. IstoÉ faz pastiche de Veja para demonstrar, ironicamente, que as falas contraditórias poderiam ser aplicadas tanto à candidata Dilma quanto ao candidato Serra. As falas dele foram pinçadas em seus discursos sobre o caso de corrupção no governo paulista, mostrando a contradição do candidato de um dia para o outro: "Não sei quem é Paulo Preto. Nunca ouvi falar" / José Serra, no dia 11 de outubro, sobre Paulo Vieira de Souza, acusado de desviar R\$ 4 milhões da campanha do PSDB e "Evidente que eu sabia do trabalho do Paulo Souza, que é considerado uma pessoa muito competente" / José Serra, no dia 12 de outubro, sobre Paulo Vieira de Souza, acusado de desviar R\$ 4 milhões da campanha do PSDB.

Os acontecimentos vão tomando forma a partir da leitura que associa as revistas de uma mesma semana entre si e a que as associa a revistas de outras semanas, a outras referências, a outros textos. O princípio do ideograma desenvolvido por Eisenstein e apropriado por Vaz (2009) para as newsmagazines e a ideia desenvolvida no Animalário nos são muito caras por possibilitarem pensar na criação de um novo conceito por cada revista e num leitor que tem autonomia e criatividade na apreensão dos acontecimentos.

Nossa proposta de análise é viabilizada por essa noção de texto que percebe de modo articulado o verbal e o visual: o ato de leitura resulta dessa complexa rede de textos. Acreditamos que essa noção permite pensar as diversas possibilidades de leitura dos acontecimentos decorrentes da organização de cada capa, da disposição das revistas nas bancas e das capas em relação a outras capas que tenham sido memorizadas. É nesse sentido que apostamos no texto como um caminho de apreensão dos acontecimentos. 


\section{CONSIDERAÇÕES}

As newsmagazines brasileiras renovam a oferta de acontecimentos em suas capas a cada sete dias. Acontecimentos construídos no ato do consumo tanto por seus leitores habituais quanto por aqueles que têm contato esporádico com tais revistas. Nos dois casos entra em jogo a relação dessas publicações com outras que podem estar dispostas nos pontos de vendas e também na memória dos leitores. A significação desses acontecimentos estampados nas capas é indissociável da leitura que é feita deles. O movimento de apreensão dos mesmos nos parece uma questão bastante instigante.

Numa tentativa de discorrer sobre tal questão, neste trabalho propomos pensar a capa de newsmagazine como um texto e o texto como uma possibilidade de apreensão do acontecimento. Para tanto, nos é muito relevante, como apontam Kress, Leite-Garcia e van Leewen (2000), levar em consideração o caráter multimodal dos textos e perceber os elementos verbais e imagéticos como indissociáveis numa análise. Abril (2007) contribui fortemente, entre outros aspectos, ao reiterar que os textos não estão isolados no mundo, que sempre recebemos conjuntos, avalanches de texto. Flusser (2010), por sua vez nos acrescenta ao dizer que o texto só é completado na recepção.

Essa noção que toma o texto como algo multimodal, pressupõe a existência de outros textos e se completa apenas com o trabalho de leitura (que vai evocar outros textos), parecenos uma nova possibilidade de caminho de apreensão do acontecimento.

As eleições presidenciais de 2010 podem ser contadas de distintos modos por cada veículo. Se para Veja, por exemplo, Dilma é contraditória, para Carta Capital da mesma semana, a acusação não passa de oportunismo eleitoral. Para IstoÉ da semana seguinte, Serra é ainda mais incoerente, muda de opinião de um dia para o outro. E para o leitor que teve contato apenas com uma dessas revistas? E para aquele que teve contado com duas delas? E quem teve contato com todas? A apreensão de tal acontecimento não está limitada às formas como as eleições foram reportadas. O momento da leitura proporciona novos olhares. Parece haver novidades a cada leitura. É como se o acontecimento fosse recriado por cada um que tem contato com materiais que dizem dessas eleições, de acontecimentos semelhantes. Importa quem organiza os materiais simbólicos, como eles são dispostos nas bancas de revista, a ordem de leitura, importa quem lê, o modo como lê.

Se por um lado a noção de texto permite um avanço no nosso modo de observar os acontecimentos nas capas das revistas semanais de informação, ainda é necessário buscar 
outros conceitos que, aliados a essa noção, deem conta da complexidade envolvida quando sugerimos pensar no texto como possibilidade de apreensão do que ocorre no mundo e afeta a vida dos sujeitos.

\section{REFERÊNCIAS}

ABRIL, G. Análisis crítico de textos visuales. Madrid: Editorial Sintesis, 2007.

ANTUNES, Elton; VAZ, Paulo Bernardo. Mídia: um aro, um halo e um elo. In: GUIMARÃES, César; FRANÇA, Vera (Orgs.). Na mídia, na rua: narrativas do cotidiano. Belo Horizonte: Autêntica, 2006. p.43-60.

CARDOSO, Carla Rodrigues. Nos bastidores do óbvio: A capa de newsmagazine como Dispositivo de Comunicação. Anais do V Congresso da Associação Portuguesa de Ciências da Comunicação. Minho: Universidade de Minho, 2007.

CHARAUDEAU, Patrick. Discurso das Mídias. São Paulo: Contexto, 2006.

FLUSSER, Vilém. A escrita. Há futuro para a escrita?. São Paulo: Annablume, 2010.

MOUILLAUD, Maurice; PORTO, Sergio Dayrell; PORTO, Sérgio Grossi. O Jornal: da forma ao sentido. Brasília: Ed. UnB, 2002.

MURUGARREN, Miguel; CASTÁN, Javier Sáez. Animalário Universal do Professor Revillod. Lisboa: Orfeu Negro, 2009.

QUÉRÉ, Louis. Entre facto e sentido: a dualidade do acontecimento. Trajectos n. 6. Lisboa: Lisboa, 2005.

SCALZO, Marília. Jornalismo de revista. São Paulo: Contexto, 2008.

KRESS, Gunther; LEITE-GARCIA, Regina; VAN LEEUWEN. Semiótica Discursiva. In.: VAN DIJK, Teun A. El discurso como estructura y proceso. Barcelona: Gedisa, 2000.

VAZ, Paulo Bernardo Ferreira. Capas de newsmagazines brasileiras: produção e apropriação de sentidos. In: VIII LUSOCOM, 2009, Portugal. VIII LUSOCOM Comunicação, Espaço Global e Lusofonia. Lisboa : Universidade Nova de Lisboa, 2009.

VAZ, Paulo Bernardo Ferreira; FRANÇA, Renné Oliveira. Entre o legítimo e o legitimado: a explosão dos acontecimentos nas capas de Veja. In: XVIII Encontro da Compós - Anais. Belo Horizonte: Associação Nacional dos Programas de Pós-Graduação em Comunicação, 2009.

Original recebido em:14/11/2011

Aceito para publicação em: 29/11/2011

ANIMUS R. Interamericana de Comunicação Midiática, http://www.ufsm.br/revistas E-ISSN 2175-4977, v. 10, n. 20, 2011 
Resumos sobre os autores

Paulo Bernardo Ferreira Vaz é professor do Programa de PósGraduação em Comunicação Social da UFMG; pesquisador associado do CNPq; participante do GRISGrupo de Pesquisa em Imagem e Sociabilidade da UFMG.

Vanessa Costa Trindade é mestranda do Programa de PósGraduação em Comunicação Social da UFMG, bolsista da CAPES; pesquisadora do GRIS- Grupo de Pesquisa em Imagem e Sociabilidade da UFMG. 